\title{
Condições Higiênico-Sanitárias de Estabelecimentos Elaboradores de Cachorro-Quente no Município de Palotina - PR
}

\author{
Ana Paula Perin (I), Camila Lampugnani (I), Cibeli Viana (I), Luciano \\ dos Santos Bersot (I) \\ (I) UFPR - Universidade Federal do Paraná (Rua Pioneiro 2153, CEP: 85950-000, Palotina -
} $\mathrm{PR})$

\section{Resumo}

O aumento do consumo de lanches do tipo fast-food faz aumentar também a preocupação com a forma como esses alimentos são preparados, sendo necessário realizar uma investigação constante e atualizada deste tipo de comércio. O objetivo deste estudo foi verificar as condições higiênicosanitárias de estabelecimentos elaboradores de cachorro-quente no município de Palotina, Paraná. As atividades desenvolveram-se entre maio de 2013 e janeiro de 2014. Fizeram parte desse trabalho nove estabelecimentos elaboradores de cachorro-quente, sendo seis com estrutura fixa e três móveis (trailers), representando $100 \%$ do total existente no município, segundo levantamento da vigilância sanitária municipal. Foram realizadas visitas aos estabelecimentos, onde foi avaliada a situação higiênica de cada um deles (através de check-lists), realizado treinamento com os manipuladores para corrigir as não conformidades encontradas e também coletadas amostras de água, cachorro-quente e maionese para análise microbiológica. Os check-lists foram desenvolvidos baseando-se na RDC n ${ }^{\circ} 275$ da ANVISA e os estabelecimentos, após a avaliação, classificados em "bom", "regular" ou "ruim". As análises microbiológicas e os padrões seguiram metodologias oficias do MAPA e do Ministério da Saúde. Estas atividades estiveram relacionadas com as ações do Programa de Residência em Medicina Veterinária da Área de Inspeção de Produtos de Origem Animal da UFPR, Palotina. Dos nove estabelecimentos

\footnotetext{
Referência:

Ana Paula Perin, Camila Lampugnani, Cibeli Viana, Luciano dos Santos Bersot. Condições Higiênico-Sanitárias de Estabelecimentos Elaboradores de Cachorro-Quente no Município de Palotina - Pr. In: Anais do 12o Congresso Latinoamericano de Microbiologia e Higiene de Alimentos - MICROAL 2014 [= Blucher Food Science Proceedings, num.1, vol.1]. São Paulo: Editora Blucher, 2014. DOI 10.5151/foodsci-microal-121
} 
avaliados, seis $(66,7 \%)$ apresentaram resultado "bom" na avaliação do check-list e três $(33,3 \%)$ resultado "regular". Nenhuma das nove amostras de água analisadas encontrou-se fora dos padrões microbiológicos legais. Duas amostras de maionese $(22,2 \%)$ apresentaram-se impróprias ao consumo, com contagem de coliformes a $45^{\circ} \mathrm{C}$ acima do valor estabelecido pela legislação. Uma amostra de cachorro-quente $(11,1 \%)$ também apresentou-se imprópria, com contagem de coliformes a $45^{\circ} \mathrm{C}$ acima do permitido. Não foi detectada a presença de Salmonella sp. nas amostras. Pelos resultados observou-se boas condições gerais dos estabelecimentos avaliados, com a ressalva da necessidade de fazer um acompanhamento periódico dos mesmos, principalmente em virtude dos resultados analíticos encontrados, a fim de garantir a produção de alimentos com qualidade e seguros aos consumidores.

Palavras-Chave: boas práticas , trailers, manipuladores Agência de Fomento: 